\title{
Distributional records for Loxopholis rugiceps Cope, 1869 (Squamata, Gymnophthalmidae) in Central America
}

\author{
José Manuel Mora ${ }^{1}$, Mario Roberto Espinal², Gerardo Chaves ${ }^{3}$, Lucía Isabel López ${ }^{4}$ \\ 1 Maestría en Desarrollo Sostenible, Sede de Occidente, Universidad de Costa Rica, San Ramón, Costa Rica. 2 Centro Zamorano de Biodiversidad, \\ Escuela Agrícola Panamericana, Honduras. 3 Museo de Zoología, Universidad de Costa Rica, San Pedro de Montes de Oca, Costa Rica. 4 Unidad \\ de Ciencias Básicas y Carrera de Tecnología de Alimentos, Sede Atenas, Universidad Técnica Nacional. Atenas, Costa Rica. \\ Corresponding author: José Manuel Mora, josemora07@gmail.com
}

\begin{abstract}
Only 2 lizard species of the 11 members of the genus Loxopholis Cope, 1869 are found in Central America, L. southi (Ruthven \& Gaige, 1924) from Costa Rica to Colombia and L. rugiceps Cope, 1869 from Panama and Colombia. We report new country records for L. rugiceps from Honduras and Costa Rica. We collected 4 individuals of this species in Honduras in 2018 and 2 specimens in Costa Rica in 1997 and 2017. We discuss the distribution of L. rugiceps in Central America.
\end{abstract}

Key words

Costa Rica, Departamento de Cortés, Honduras, Loxopholis southi, Mesoamerica.

Academic editor: Edward A. Myers | Received 20 February 2019 | Accepted 10 April 2019 | Published 10 May 2019

Citation: Mora JM, Espinal MR, Chaves G, López LI (2019) Distributional records for Loxopholis rugiceps Cope, 1869 (Squamata, Gymnophthalmidae) in Central America. Check List 15 (3): 363-368. https://doi.org/10.15560/15.3.363

\section{Introduction}

The family Gymnophthalmidae currently is known to contain 257 species (Uetz 2019) of small to mediumsized lizards, which inhabit several habitat types in Central and South America (Vitt and Caldwell 2009, Meza-Joya and Ramos-Pallares 2015). Gymnophthalmid lizards of the genus Loxopholis Cope 1869 are small (snout-vent length $<50 \mathrm{~mm}$ ) species but form an important component of the leaf-litter herpetofauna of Neotropical forests (Dixon and Soini 1986, Rodrigues et al. 2002). This genus primarily is South American in distribution, as among the 11 currently recognized species, only 2 are known to occur in Lower Central America (Köhler 2008, Uetz 2019), Loxopholis southi Ruthven \& Gaige, 1924 and Loxopholis rugiceps Cope, 1869.
Loxopholis rugiceps was described from the "Magdalena River region, Nueva Granada" in Colombia (Cope 1869: 305). Ruibal (1952) included Cope's genus Loxopholis in Leposoma Spix, 1825 (Goicoechea et al. 2016). Loxopholis rugiceps has been reported from Panama and Colombia (Köhler 2008, Uetz 2019), with the province of Bocas del Toro in extreme western Panama as the northernmost point of distribution (Lotzkat et al. 2012).

Wilson et al. (2010) provided an extensive summary of the Mesoamerican herpetofauna, and since that time, several important contributions from throughout this region have been published. In Honduras, McCranie (2018) provided an extensive list of bibliographical references for much of the work that has been conducted in that country and highlighted the available knowledge 
on its reptile fauna. Unfortunately, much of the original habitat in Honduras has been lost (Mora et al. 2018, McCranie 2018) at a time when there is still much to learn about reptiles of that country. Accordingly, even such simple contributions as new localities for various reptile species are valuable. The same also is true for Costa Rica, as well for other countries in Mesoamerica. Nonetheless, some reports of species found in new localities are limited to the report itself, and additional information is necessary to help understand the reasons why certain species are being reported from new locations. For example, Espinal and Mora (2019) not only reported a new locality for Mesoscincus managuae (Dunn, 1933) on the Caribbean versant of Honduras, a largely Pacific coastal lowland dry forest species, but also provided an ecological and biogeographical explanation for this find.

The current literature is replete with reports of new localities for species of numerous taxa. Among other possibilities, these reports show at least 2 aspects of great importance: dispersal movements of several species due to various factors (Mora and López 2011) and a lack of information on the natural history of the species, including such basic data as their distributional ranges. Of course, linked to their distribution are aspects related to negative impacts, survival, and adaptation that we do not fully understand (Espinal and Mora 2019).

Information on the geographic distribution of gymnophthalmid lizards remains incomplete mainly because many species are fossorial or semi-fossorial in their habits (Meza-Joya and Ramos-Pallares 2015) and because inventories of lizard faunas in areas within distributional ranges of these species are scarce, and thus, extensive field research is necessary (Arbeláez-Cortés 2013). Our objective is to document new localities in Honduras and Costa Rica for a gymnophthalmid species known only from South America and southern Central America; this species' northernmost distribution limit was previously documented in the province of Bocas del Toro, Panama (Lotzkat et al. 2012).

\section{Methods}

We conducted herpetofaunal surveys in the Departamento de Cortés in northern Honduras in 2018, and collected 4 individuals of Loxopholis rugiceps at 2 localities (Fig. 1). We photographed the lizards, and later preserved them using standard procedures for fluid preservation (Pisani 1973). Specimens were deposited in the Museo de Zoología at the University of Costa Rica (UCR), and in the Museo de Historia Natural UNAH-VS Biodiversidad y Ciencia, San Pedro Sula, Honduras (UVS-V). The collecting permit (DE-ICF-065-2018) was provided by the Instituto de Conservación Forestal (ICF), Tegucigalpa, Honduras. Occurrence data for L. rugiceps were obtained from the literature (Ruibal 1952, Dixon and Soini 1986, Hernández et al. 2001, Köhler 2008, Lotzkat et al. 2012, Meza-Joya and Ramos-Pallarez 2015, McCranie 2018, Uetz 2019).
Abbreviations used: SVL = snout-vent length; TL = tail length.

\section{Results}

New records. HONDURAS: Cortés: La Venta, Pimienta $\left(15^{\circ} 15^{\prime} 04^{\prime \prime} \mathrm{N}, 088^{\circ} 00^{\prime} 04^{\prime \prime} \mathrm{W} ; 50 \mathrm{~m}\right.$ alt.), collected by Mario R. Espinal, 27 October 2018, crossing a gravel road along a sugarcane field near the Rio Ulúa (Fig. 3A) at 1000h (1 male, UCR 23181, SVL $=37 \mathrm{~mm}, \mathrm{TL}=76$. Cortés: Caracol, Potrerillos (1509'15" N, 087 56'59" W; $65 \mathrm{~m}$ alt.), collected by Mario R. Espinal, 27 November 2018, in leaf litter and debris along the roots of a Ficus sp. tree (Fig. 3B) at 1100h (1 female, UVS-V-01232, SVL $=38, \mathrm{TL}=72)$. Cortés: Caracol, Potrerillos $\left(15^{\circ} 09^{\prime} 15^{\prime \prime} \mathrm{N}\right.$, $087^{\circ} 56^{\prime} 59^{\prime \prime} \mathrm{W}$; $65 \mathrm{~m}$ alt.), collected by Mario R. Espinal, 28 November 2018, in leaf litter within secondary vegetation (Fig. 3C) at 1100h (1 female, UVS-V-01233, SVL $=36, \mathrm{TL}=87)$. Cortés: Caracol, Potrerillos $\left(15^{\circ} 09^{\prime} 15^{\prime \prime} \mathrm{N}\right.$, 08756'59" W; 65 m alt.), collected by Mario R. Espinal, 15 December 2018 in leaf litter within secondary vegetation (Fig. 3D) at $1730 \mathrm{~h}(1$ male, UVS-V-01234, SVL = $32, \mathrm{TL}=68 \mathrm{~mm})$.

Other specimens examined. While examining and comparing the first specimen collected, we discovered 2 specimens of $L$. rugiceps that previously had been identified as L. southi.

COSTA RICA: Limón: Talamanca, Sixaola, San Mi-

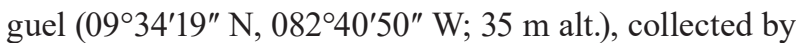
Gerardo Chaves, 28 January 1997 (1 female, UCR 12967). Limón: Talamanca, Sixaola, Manzanillo $\left(09^{\circ} 38^{\prime} 15^{\prime \prime} \mathrm{N}\right.$, 082³8'45" W; 25), collected by Jairo Moya Ramírez, 14 May 2017 (1 male, UCR 22983).

Identification. Initially, Larry David Wilson identified the species, and we later confirmed its identity by conducting a review of the pertinent literature (Ruibal 1952, Rodrigues 1997, Rodrigues et al. 2002, Goicoechea et al. 2016) and by examining specimens in the UCR collection and conducting a morphological analysis. We used keys to separate and identify L. southi and the Honduras specimens.

The Honduran specimens were identified as Loxopholis rugiceps by the presence of 1 frontonasal instead of 2, as in L. southi. The scale counts for UCR 23181 are as follows: transverse dorsal rows 21 , transverse ventral rows 23 , gulars 10 , and number of scales from parietals to posterior margin of hind limbs 27 . The scales in L. rugiceps are keeled on the side of neck and are imbricate and shaped like the dorsals, and the prefrontals are in contact medially and are slightly smaller than the frontoparietals (Ruibal 1952). The temporals are large and keeled, and a single anterior postmental is present, which is followed by 2 pairs of postmentals that are in contact medially. Longitudinal rows of enlarged gulars are absent in this species. The scales on the limbs are keeled, except for on the posterior surface of the hind limbs, the subcaudals are elongate, keeled, and arranged in longitudinal 


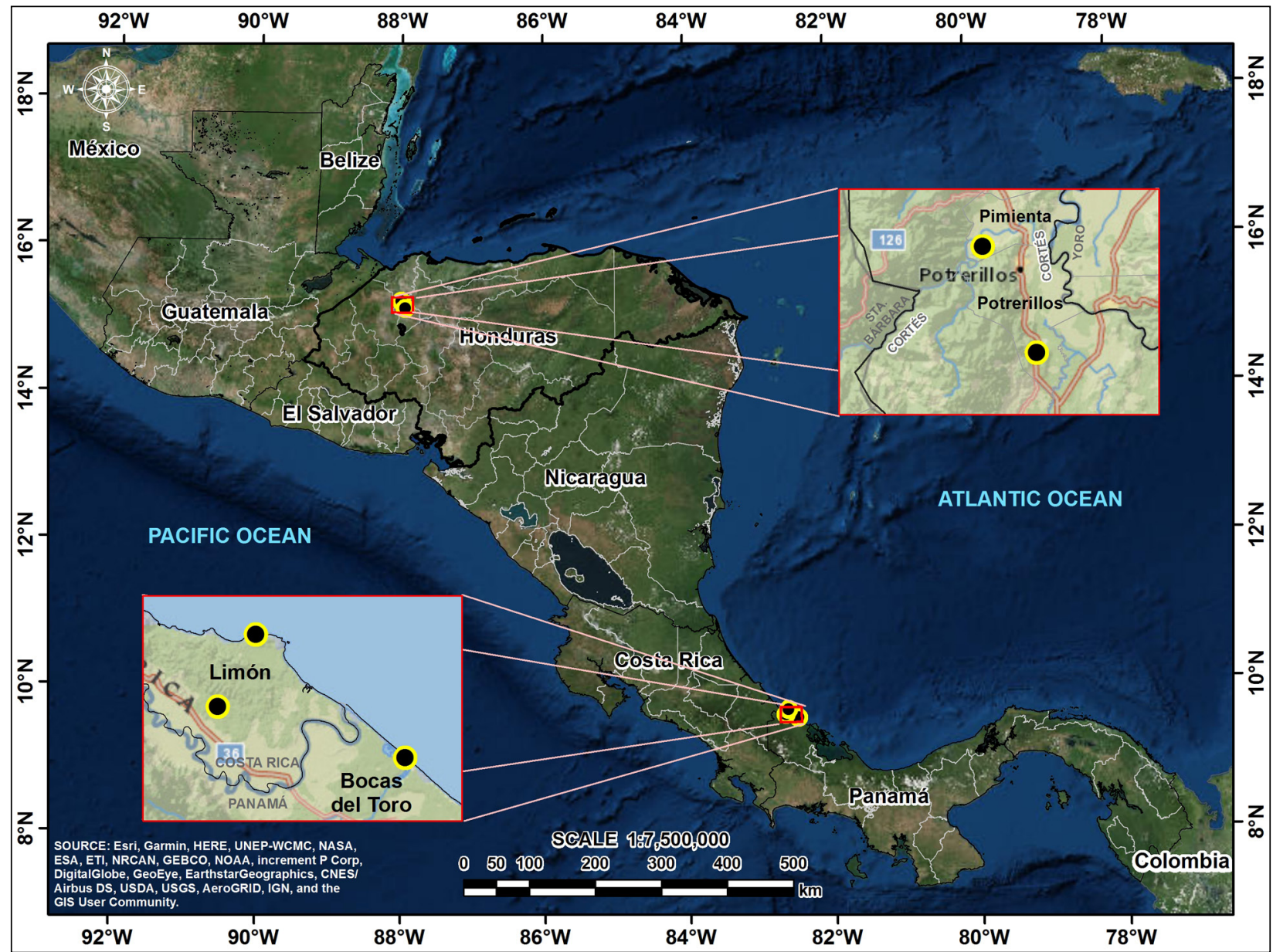

Figure 1. Localities of new records (black dots) for Loxopholis rugiceps in Departamento de Cortés, Honduras, and Limón, Costa Rica, and the northernmost known locality for this species in Bocas del Toro, Panamá.

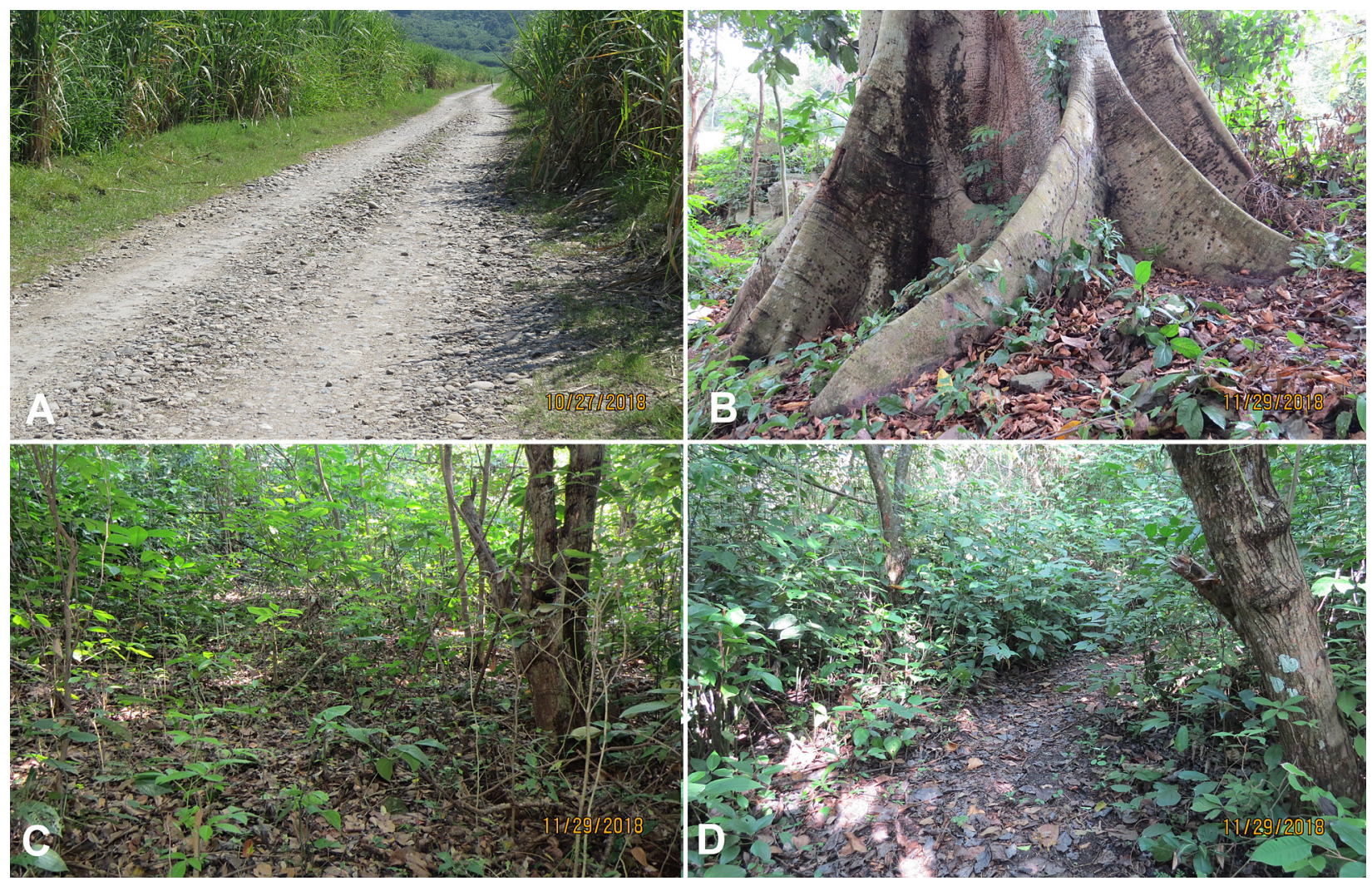

Figure 2. Collecting points for 4 individuals of Loxopholis rugiceps in the Departamento de Cortés, Honduras.. A. Male UCR 23181. B. Female UVS-V-01232. C. Female UVS-V-01233. D. Female UVS-V-01234. 


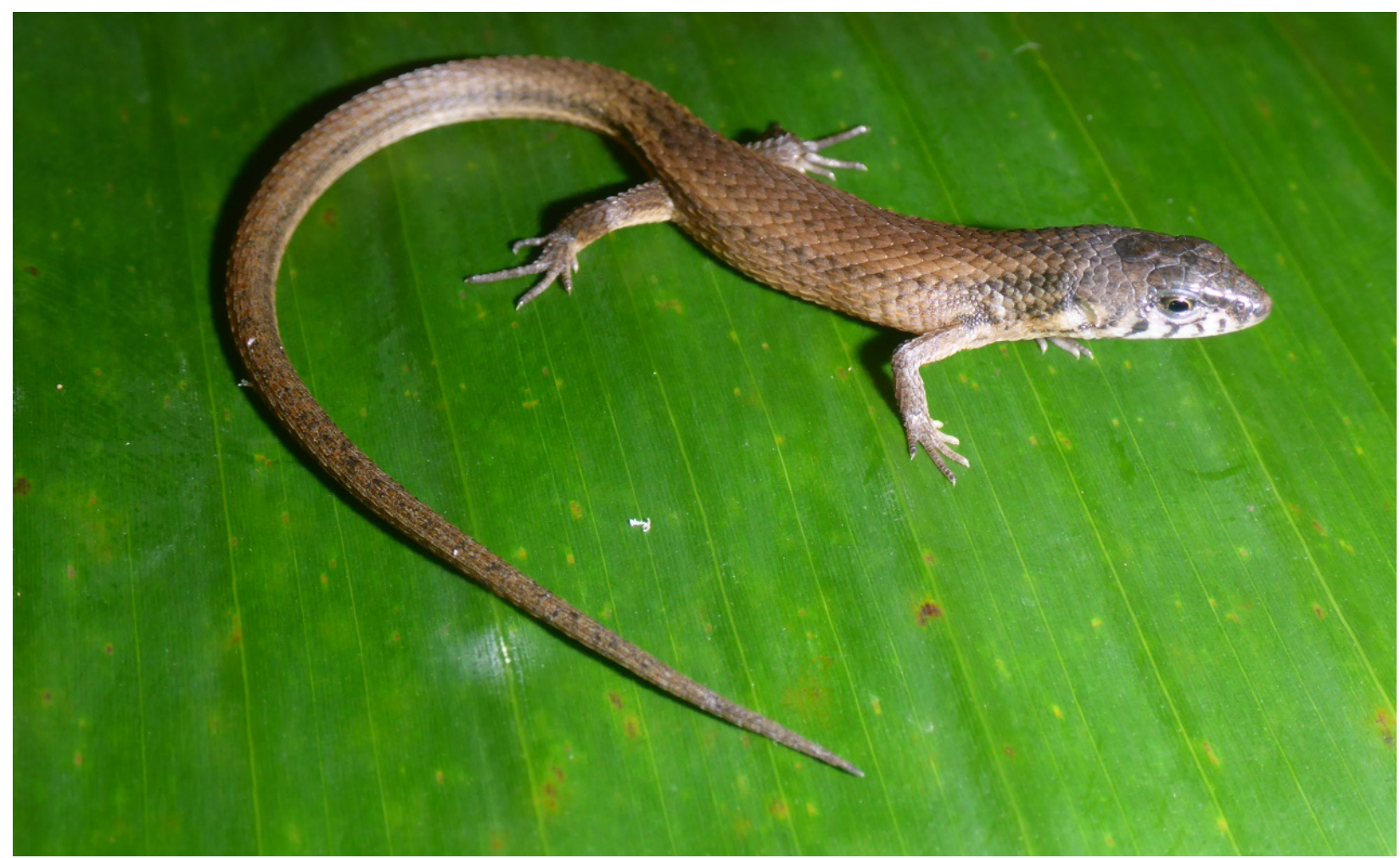

Figure 3. An individual of Loxopholis rugiceps (UVS-V-01232, Departamento de Cortés, Honduras) showing all the characteristics that separate this species from others in the genus.

and transverse rows, and the caudals are broad, keeled, and only form longitudinal rows on the last two-thirds of the tail (Ruibal 1952). The dorsum of our specimens is brown with the lateral surfaces dark brown or black, and with the tip of the scales white. The side of the neck is similar in color to the sides of the body in this species, but also includes diagonal rows of white scales. The dorsum is slightly paler than the top of the head (Ruibal 1952). Our specimens from Departamento Cortés agree well with this description, and contain all the key characteristics mentioned therein (Fig. 3).

\section{Discussion}

As currently understood, the gymnophthalmid genus Loxopholis Cope 1869 contains 11 species of small, leaflitter-dwelling lizards that occur in Neotropical forests in Central and South America (Pellegrino et al. 2011, Uetz 2019). These lizards occur exclusively in tropical forested areas and previously were known from Costa Rica to the Atlantic slopes of eastern Brazil (Rodrigues 1997). Only 2 species have been reported in Central America: $L$. southi from Costa Rica to Colombia and $L$. rugiceps from the province of Bocas del Toro, Panama to Santa Marta and Valle de Rio Magdalena in Colombia (Rodrigues 1997).

Because these species prefer cryptic microhabitats (leaf litter, caves, roots, and fallen trunks), they are often difficult to observe (Hernández et al. 2001). The secretive habits of species of Loxopholis might explain why $L$. rugiceps had not been previously reported from
Honduras. Still, given the abundance of L. rugiceps in the study area, we find it surprising that this species had gone unnoticed. A possibility is that most herpetologists conduct their research in protected areas or pristine habitats and not in the disturbed areas that are now more extensive.

It would seem logical that $L$. rugiceps should be present in the intervening area, namely along the Caribbean lowlands of Nicaragua and most of Costa Rica. We can only surmise that within this distributional gap $L$. rugiceps is absent or present but not collected, or present and collected but misidentified as $L$. southi. The last supposition has proved to be the case, as we can confirm that 2 specimens, collected previously but misidentified, have been found in the Caribbean lowlands of Costa Rica. These specimens help fill the distributional gap and provide a better understanding of the total distributional range of L. rugiceps.

Assuming that the Honduras population is autochthonous, the possibility that L. rugiceps is absent in this distributional gap seems highly unlikely, given the presence of suitable habitat throughout most, if not all, of the intervening region, and the 2 Costa Rican specimens support this supposition. Nonetheless, we cannot rule out that the population of L. rugiceps found in Honduras might have been introduced, as a specimen was reported to have reached the United States in a shipment of bananas from Panama (Lotzkat et al. 2012).

An explanation as to how L. rugiceps turned up in Honduras remains an enigma. Ancient temporal diversification (pre-Pleistocene) of Neotropical fauna often 
has been reported for several lizards and snakes (Pellegrino et al. 2011). Thus, a Pliocene colonization of Central America by L. southi during the rise of the Isthmus of Panama is possible (Pellegrino et al. 2011), and this occurrence might also explain the distribution of $L$. rugiceps. These patterns of diversification might be related to different major climatic variations associated with marine transgressions, geotectonic processes, and river dynamics, and a single model of vicariance or climatic changes does not reflect the complexity of speciation in the Neotropics (Pellegrino et al. 2011).

Unfortunately, the combination of habitat loss and global climate change are causing a rearrangement of the faunas, which will lead to unpredictable consequences on their ecosystems, their functioning, and, above all, on the services and goods that human beings will obtain from them (Mora and López 2011). The redistribution of life on Earth has emerged as one of the most biologically significant responses to anthropogenic global warming (Sunday et al. 2012). Several species already are experiencing changes in distribution, primarily related to elevation, as a result of changes in temperatures (Hannah et al. 2007). Apparently, distributional changes related to an increase in deforested areas used by generalist species also are occurring (Mora and López 2011). Presently, we are not aware if the ancestral and recent distributions of L. rugiceps in Central America are related to any of these causes, but we pose the question here.

\section{Acknowledgements}

We thank Larry David Wilson for confirming the identification of our specimen, as well as for providing advice and corrections regarding the manuscript. Louis W. Porras made valuable comments and suggestions that greatly improved the manuscript. José Mario Solis provided the measurements of the specimens. We thank Jorge Luis Funez Medina for preparation of Figure 1 and Profesionales de la Construcción (PRODECON) for financing the fieldwork.

\section{Authors' Contributions}

JMM wrote the manuscript and helped to manage all information; MRE collected the Honduras specimens, collected the data and took the photographs; GC identified the specimens and provided the data of the Costa Rica specimens; LIL helped to develop the manuscript and provided and analyzed literature. All authors read, edited, and approved the manuscript.

\section{References}

Arbeláez-Cortés E (2013) Knowledge of Colombian biodiversity: published and indexed. Biodiversity and Conservation 22 (12): 2875-2906. https://doi.org/10.1007/s10531-013-0560-y

Cope, ED (1869) Sixth contribution to the herpetology of Tropical America. Proceedings of the Academy of Natural Sciences of Philadelphia (1868) 20: 305-313.
Dixon JR, Soini P (1986) The Reptiles of the Upper Amazon Basin, Iquitos Region, Peru. Milwaukee Public Museum, Milwaukee, 154 pp. https://doi.org/10.1163/156853888x00422

Espinal M, Mora JM (2019) Distribution extension of a dry forest species: Mesoscincus managuae Dunn, 1933 (Scincidae), in the Caribbean versant of Honduras. Check List 15 (2): 269-273. https://doi.org/10.15560/15.2.269

Goicoechea N, Frost DR, De la Riva I, Pellegrino KCM, Sites Jr J, Rodrigues MT, Padial JM (2016) Molecular systematics of teioid lizards (Teioidea/Gymnophthalmoidea: Squamata) based on the analysis of 48 loci under tree-alignment and similarity-alignment. Cladistics 32 (6): 624-671. https://doi.org/10.1111/cla.12150

Hannah L, Midgley G, Andelman S, Araújo M, Hughes G, MartinezMeyer E, Pearson R, Williams P (2007) Protected area needs in a changing climate. Frontiers in Ecology and Environment 5 (3): 131-138. http://doi.org/cb2wx3

Hernández REJ, Castaño OV, Cárdenas G, Galvis PA (2001) Caracterización preliminar de la comunidad de reptiles en un sector de la Serranía del Perijá, Colombia. Caldasia 23 (2): 475-489.

Köhler G (2008) Reptiles of Central America. 2nd edition. Herpeton, Offenbach, $400 \mathrm{pp}$.

Lotzkat S, Hertz A, De Leon R, Köhler G (2012) Distribution extension for Leposoma rugiceps (Cope, 1869) (Squamata: Gymnophthalmidae) in Panama, with first record from Bocas del Toro Province. Check List 8 (3): 520-524. https://doi.org/ 10.15560/8.3.520

McCranie JR (2018) The Lizards, Crocodiles, and Turtles of Honduras Systematics, Distribution, and Conservation. Bulletin of the Museum of Comparative Zoology, Special Publications Series, No. 2, Harvard University, Cambridge, Massachussetts, 666 pp. https://doi.org/10.5962/bhl.title.155244

Meza-Joya L, Ramos-Pallares E (2015) New records, range extensions and updated distribution of two gymnophthalmid lizards from the Caribbean Region, Colombia. Check List 11 (5): 1735. https://doi. org/10.15560/11.5.1735

Mora JM, López LI (2011) Cambios en la Distribución de las Aves: ¿Qué Puerta Hemos Abierto?; los Casos del Chico Piojo (Campylurhynchus rufinucha) y la Paloma Ala Blanca (Zenaida asiatica) en Costa Rica. Ceiba 52 (2): 230-236. https://doi.org/10.5377/ ceiba.v52i2.1760

Mora JM, López LI, Espinal M, Marineros L, Ruedas L (2018) Diversidad y conservación de los murciélagos de Honduras. MiAmbiente+, Tegucigalpa, 284 pp.

Pellegrino KCM, Rodrigues MT, Harris DJ, Yonenaga-Yassuda Y, Sites Jr JW (2011) Molecular phylogeny, biogeography and insights into the origin of parthenogenesis in the Neotropical genus Leposoma (Squamata: Gymnophthalmidae): ancient links between the Atlantic Forest and Amazonia. Molecular Phylogenetics and Evolution 61 (2): 446-459. https://doi.org/10.1016/j. ympev.2011.07.010

Pisani GR (1973) A Guide to Preservation Techniques for Amphibians and Reptiles. Society for the study of amphibians and reptiles. Miscellaneous Publications, Herpetological Circular No. 1. University of Kansas, Lawrence, $22 \mathrm{pp}$.

Rodrigues MT, Dixo M, Accacio GM (2002) A large sample of Leposoma (Squamata, Gymnophthalmidae) from the Atlantic Forests of Bahia, the status of Leposoma annectans Ruibal, 1952, and notes on conservation. Papéis Avulsos de Zoologia 42 (5): 103-117. https://doi.org/10.1590/s0031-10492002000500001

Rodrigues MT (1997) A new species of Leposoma (Squamata: Gymnophthalmidae) from the Atlantic forest of Brazil. Herpetologica 53 (3): 383-389.

Ruibal R (1952) Revisionary studies of some South American Teiidae. Bulletin Museum Comparative Zoology 106 (11): 474-529.

Sunday JM, Bates AE, Dulvy NK (2012) Thermal tolerance and the global redistribution of animals. Nature Climate Change 2 (9): 686-690. https://doi.org/10.1038/nclimate1539

Uetz P, Freed P, Hosek J (Eds) (2019) The Reptile Database, http:// 
www.reptile-database.org Accessed on: 2019-04-28.

Vitt LJ, Caldwell J (2009) Herpetology: an Introductory Biology of Amphibians and Reptiles. Academic Press, San Diego, California, $697 \mathrm{pp}$.
Wilson LD, Townsend JH, Johnson JD (2010) Conservation of Mesoamerican Amphibians and Reptiles. Eagle Mountain Publishing, Eagle Mountain, Utah, 812 pp. 